\title{
Effect of Sand Gradation and Fines Type on Liquefaction Behaviour of Sand-fines Mixture
}

\author{
Md. Mizanur Rahman ${ }^{1}$, S.M. ASCE and Sik-Cheung Robert Lo ${ }^{2}$ \\ ${ }^{1} \mathrm{PhD}$ Student, University of New South Wales at Australian Defence Force Academy, ACT-2600 \\ Australia; mmrahman@adfa.edu.au \\ ${ }^{2}$ Associate professor, University of New South Wales at Australian Defence Force Academy, ACT- \\ 2600 Australia; r.lo@adfa.edu.au
}

\begin{abstract}
Equivalent granular void ratio and equivalent granular steady state line was used as the common basis for synthesizing test results. In isolating the influence of host sand, two sand-fines mixes with different host sand, but the same fines type and content, were tested. The influence of fines type was then investigated by testing Sydney sand mixed with three different types of fines. Scanning Electron Microscope (SEM) photography was also used to elucidate the role of angularity of fines. This led to the finding that the angularity of fines may need to be considered in determining equivalent granular void ratio.
\end{abstract}

\section{INTRODUCTION}

The factors that control the liquefaction of clean sand are well-understood. However, the understanding of liquefaction behaviour of sand with fines is less complete. There is a lack of concensus of opinion on whether the inclusion of fines will increase or reduce the liquefaction tendency. Unexpected behaviour trend was reported Yamamuro and Lade (1998) and independently confirmed by Bobei and Lo (2005). Some researchers suggested that void ratio may not serve as a consistent basis for comparison because the fine particles may be trapped in between sand particle and remain inactive on sand force structure (Georgiannou et al. 1990; Kuerbis et al. 1988; Thevanayagam 1998). Alternate state variables such as inter-granular void ratio or equivalent granular void ratio have been proposed for unifying the liquefaction behaviour of clean sand and sand with fines. However, these studies mainly concentrated on studying the influence of fines content. As such, both the host sand and fines type were fixed in these studies. This paper presents some preliminary findings on the influence of both host sand gradation and fines type on the liquefaction behaviour of sand-fines mixture where the "fines in sand" model is still valid. 


\section{BACKGROUND}

Three important aspects on the liquefaction behaviour of sand-fines mixture will be discussed in this section.

\section{Equivalent Granular Steady State Line}

The critical state soil mechanics (CSSM) framework has been used to characterize the liquefaction behaviour of sand. This methodology relies on knowing the Steady State Line of the soil (SSL). Note that the SSL may be curved even though it is still referred to as "line". However, location of the SSL can be strongly dependent on fines content. This lead to some practical difficulties in applying the CSSM framework to sand-fines mix, because each fines content requires its own SSL.

There is a potential problem in the use of void ratio as a state variable because the fines may simply get trapped in the void space between the sand particles and remain inactive in the force chain of the solid skeleton. Mitchell (1976) may be the first publication that suggested that the clay particles in a coarse matrix may not play any active role in the force chain of a granular phase structure. This rationale was confirmed by Kenny (1977) and Troncoso and Verdugo (1985). By considering fines as inactive, ie as void space, Thevanayagam and co-workers (1998; 1999; 2000) proposed, in lieu of void ratio, inter-granular void ratio $e_{\mathrm{g}}$, defined by Eqn (1) below as the alternative state parameter.

$$
e_{g}=\frac{e+f_{c}}{1-f_{c}}
$$

where $e=$ void ratio and $f_{\mathrm{c}}=$ fines content in decimal. The assumption that fines can be treated as void space is not universally applicable. For higher $f_{c}$ or larger fines size relative to host sand, some fraction of fines will have to get between the host sand grains and participate in force structure. Thevanayagam et al. (1999; 2000) proposed the general concept of equivalent granular void ratio, $e^{*}$, defined as:

$$
e^{*}=\frac{e+(1-b) f_{c}}{1-(1-b) f_{c}}
$$

where $b=$ fraction of fines which actively take part in the force structure of the solid skeleton. When $b=0$, equivalent granular void ratio reduces to inter-granular void ratio. However, most literature deduced the " $b$ " values by back-analysis, as such test results for a range of fines content has to be known as a priori. Rahman and Lo (2007b), recognizing the analogy between " $b$ "-value and binary packing, suggested that " $b$ " should be a function of both particles size ratio, $(r)$ and fines content, $\left(f_{c}\right)$, i.e. $b=\mathrm{B}\left(r, f_{\mathrm{c}}\right)$. The size ratio, $r$, is defined by $r=\left(\mathrm{d}_{50} / \mathrm{D}_{10}\right)$ where $\mathrm{d}_{50}=$ median size for fines and $\mathrm{D}_{10}=$ particle size at $10 \%$ fractile for host sand. Based on a synthesis of existing studies on binary packing, it was revealed that this functional relationship has to possess certain mathematical attributes. The details can be found in Rahman and Lo 
(2007b; Rahman et al. 2007). The following equation was found to possess the attributes required:

$$
\left.b=\left(1-e^{\left(m\left[f_{c}\right]^{n} / k\right.}\right)\right)\left(\frac{r f_{c}}{f_{\text {thre }}}\right)^{r}
$$

Where $m$ and $n$ are empirical constant, $k=\left(1-r^{0.25}\right), f_{\text {thre }}=$ threshold fines content, which is the fines content where the behaviour of sand-fines mix changes from "fines in sand" to "sand in fines". Thus the value of $f_{\text {thre }}$ is the point where the behaviour trend reverses with further increase in fines content. Eqn. (3) is applicable for $f_{\mathrm{c}}<f_{\text {thre }}$ so that the mixture remains as "fines in sand". Eqn (3) requires two fitting constants, $m$ and $n$. Rahman and Lo $(2007 \mathrm{a} ; 2007 \mathrm{~b})$, by calibrating Eqn (3) against nine databases, reported that setting $m=n=1.5$ will yield an approximately unique SSL for sand in the $e^{*}-\log \left(p^{\prime}\right)$ space, or a unique correlation between cyclic resistance and $e^{*}$. The former finding can be idealized into the concept of a unique equivalent granular SSL (in the triaxial compression plane). This idealization provides a simple means for predicting the SSL of sand with any fines content (less than that of the threshold value) from that of clean sand by the following procedure.

1. For any $p^{\prime}$ SS, on the SSL of clean sand, determine the corresponding void ratio. This void ratio is in fact $e^{*}$ of sand with fines because the SSL of clean sand is in fact the equivalent granular SSL.

2. Calculate the corresponding global void ratio, $e$, of the sand with fines by:

- First calculate " $b$ ” using Eqn. (3)

- Calculate $e$ from $e^{*}$ with Eqn. (2)

3. Repeat steps 1 and 2 for other values of $p^{\prime}$ ss so that a complete SSL for sand with fines is generated.

However, the above findings were established for non-plastic fines. It is pertinent to examine the effect of angularity and plasticity on the above conceptual framework.

\section{Effect of Host sand Gradation}

Chang et al. (1982) reported that cyclic liquefaction resistance of a clean sand was strongly affected by the mean diameter, $\mathrm{D}_{50}$, and coefficient of uniformity, CU, provided that $\mathrm{D}_{50}<0.23 \mathrm{~mm}$. However, the individual effects of $\mathrm{D}_{50}$ and $\mathrm{CU}$ were not isolated. Vaid at el. (1991) examined the effect of CU by testing three clean sands with identical mineralogy, $D_{50}$. Furthermore the grading curves of these three sands were linear. They found that cyclic liquefaction resistance of clean sand increases with $\mathrm{CU}$, at low relative density and the trend was reversed at high relative density. However, there is a scarcity of test data on the influence of CU for sand-fines mix, the subject of this paper.

\section{Effect of Fines Type}

Most of the published literatures on the liquefaction behaviour on sand fines mixture are based on non-plastic fines. Perlea et al. (1999) reported any increase in plasticity 
of fines resulted in decrease in liquefaction resistance for $f_{c}<15 \%$ and the trend reversed when $f_{c}>20 \%$. Ghahremani and Ghalandarzadeh (2006) reported that, for sand with $16 \%$ fines, cyclic liquefaction resistance increased when the plasticity index, PI, was increased from 20 to 40. Ghahremani et al. (2006) also reported for sand with $30 \%$ fines, the steady state strength of the sand-fines mix increased with increase in PI (from PI $=19$ to PI=48). However, Sadek and Saleh (2007) reported, for a sand with $10 \%$ fines, the influence of PI on cyclic liquefaction resistance depended on the value of PI relative to a threshold value (which was about $11 \%$ ). For $\mathrm{PI}<11 \%$, liquefaction resistance decreased with $\mathrm{PI}$, but for PI $>11 \%$ liquefaction resistance increased with $\mathrm{PI}$ at an insignificant rate. Thus, our understanding of the effect of plasticity of fines is far from adequate.

\section{EXPERIMEMTAL STUDY}

Experimental studies were conducted on sand-fines mixtures using two types of host sand and three types of fines. The two types of host sand are: a well-graded sand denoted as WG-sand and a uniform size sand referred to as Sydney sand. The three types of fines are: M-Silt-II, S-Silt-I and S-Silt-II. The notation "II" denotes that the fines was synthesized from two types of fines materials. The fines content were kept at 15\%. The particle size distributions of the host sands and fines are plotted in Figure 1. It is evident that a size gap between the host sand and the fines is always maintained and the intrinsic assumption of a "fines in sand" model is always satisfied.

Sydney sand is a medium quartz clean sand (SP), with a coefficient of uniformity, $\mathrm{CU}=1.26$ and it's index properties can be found in Lo et al. (1989). WG-sand is commercially available sand used in concrete industry. It has a coefficient of uniformity of 4.16. Three different fines: M-Silt-II, S-Silt-I and S-Silt-II, are used to study the effect of fines. M-Silt-II is a specially designed low plasticity fines with a coefficient of uniformity 12.56 . It is composed of $2 / 3$ of well-graded silt (CL) from the Majura River $(\mathrm{PL}=23, \mathrm{PI}=18)$ and $1 / 3$ commercial kaolin $(\mathrm{PL}=32, \mathrm{PI}=31)$. S-Silt-I is a non-plastic fines that is obtained by milling Sydney sand. S-Silt-II is synthesized from 2/3 S-Silt-I and 1/3 kaolin. A summary of the sand-fines composition and their relevance in this study are given in the Table 1.

Table 1. Summary of fines used on the study

\begin{tabular}{|c|c|c|c|c|}
\hline Fines & Comp & tion & \multicolumn{2}{|c|}{ Comparative study } \\
\hline S-Silt-I & \multicolumn{2}{|c|}{ Milled Sydney Sand (MSS) } & Effect of fines & \\
\hline S-Silt-II & 2/3 MS Sand & 1/3 kaolin & Plasticity & \multirow{2}{*}{$\begin{array}{l}\text { Effect fines } \\
\text { angularity \& } \\
\text { mineralogy }\end{array}$} \\
\hline M-Silt-II & 2/3 Majura Silt & 1/3 kaolin & & \\
\hline
\end{tabular}

\section{Specimen Preparation}

A specimen was formed by a modified moist tamping method. A pre-determined quantity of moist soil was carefully placed and then tamped lightly into a prescribed 
thickness using a standardised plastic strip with a tamping area of $8.5 \mathrm{X} 20 \mathrm{~mm}$. A total of 10 layers were placed. The dimensions of as placed soil specimens were $100 \mathrm{~mm}$ in both diameter and height. Free ends with enlarged platens were used to minimize end restraint. This technique has been proven to be successful in achieving essentially uniform deformation for a range of soil type (Lo et al. 2003; Lo and Wardani 2002). Bedding and membrane penetration errors were reduced to an insignificant value by using the liquid rubber technique developed by Lo et al. (1989). Saturation was achieved by vacuum flushing with a low head followed by back pressure saturation, both in a manner that ensured the effective stress in a specimen was less than $20 \mathrm{kPa}$. Details of the specimen preparation method are contained in Bobei and Lo (2005).

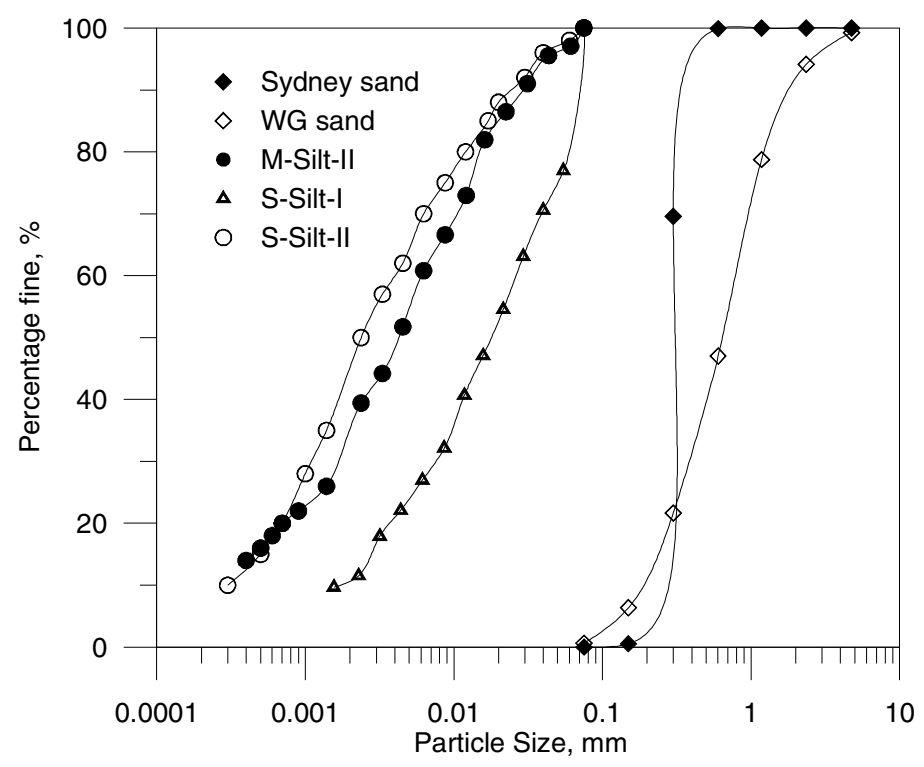

FIG. 1. Grain size distribution curve of host sand and fines.

\section{Experiment Setup}

A strain controlled triaxial loading system with fully automated data logging facilities was used for this study. Axial load was measured with an internal load cell. The axial deformation was measured by a pair of internal LVDTs mounted directly across the top platen and an external LVDT. The former was used in the early stage of shearing whereas the latter was used at large deformation. Cell pressure was controlled by a large capacity Digital Pressure Volume Controller (DPVC). The pore pressure line was connected to a small capacity DPVC for controlling back pressure (and measuring the volume change) at the consolidation stage, and for imposing an undrained condition and measuring the resultant pore pressure response. Two pressure transducers mounted on the top and bottom platen respectively were also used to verify pore pressure equilibrium.

\section{RESULT AND DISCUSSION}




\section{Effect of Host sand Gradation}

To study the influence of host sand gradation on static liquefaction behaviour, isotropically consolidated undrained (ICU) tests were conducted on two sand-fines mix. The host sand was either Sydney sand or WG-sand, but the fines type and content was fixed: $15 \%$ M-Silt-II. All specimens were prepared with exactly same amount of material so that the as-placed void ratio measured at a standardized confining stress of $20 \mathrm{kPa}$ was essentially same for all tests. The consolidation stress, $p_{0}^{\prime}$, was in the range of 350 to $850 \mathrm{kPa}$, and therefore the void ratios at start of shearing were dependent on $p^{\prime}{ }_{0}$. However, for tests with the same $p_{0}^{\prime}$, WG-sand with fines attained a smaller void ratio than Sydney sand with fines. The ratio of peak deviatoric stress to deviatoric stress at steady state, $q_{\text {peak }} / q_{\mathrm{ss}}$, was used to interpret the liquefaction susceptibility of sand-fines mix. Higher $q_{\text {peak }} / q_{\mathrm{ss}}$ indicates more liquefaction susceptibility than lower value of $q_{\text {peak }} / q_{\mathrm{ss}}$. The tests results in the form of effective stress path (ESP) and $q-\varepsilon_{1}$ curves in Figure 2(a-d). It is evident that all the tests approached the SS closely at end of shearing.

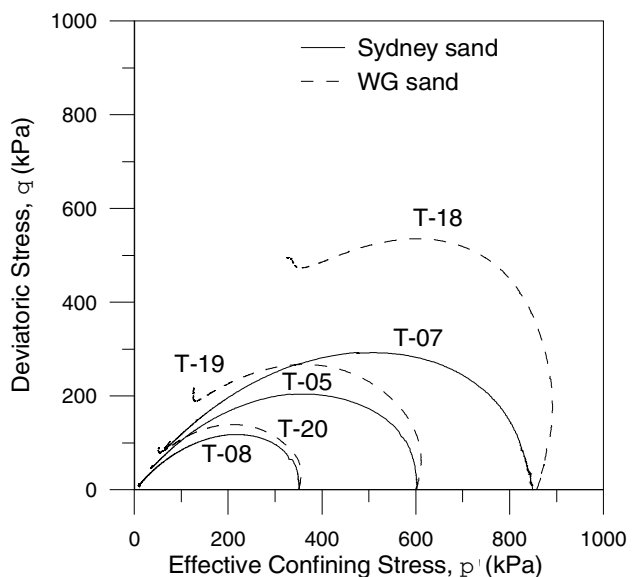

(a)

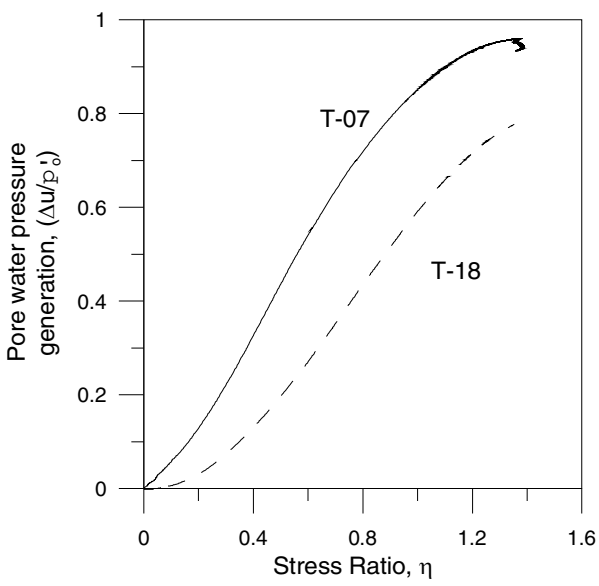

(c)

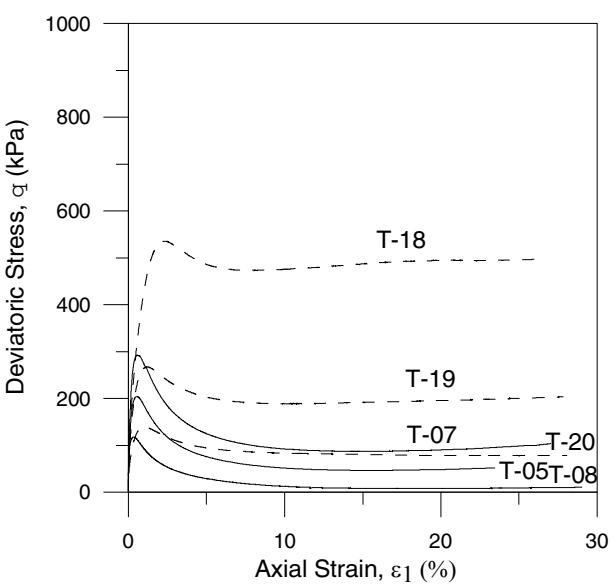

(b)

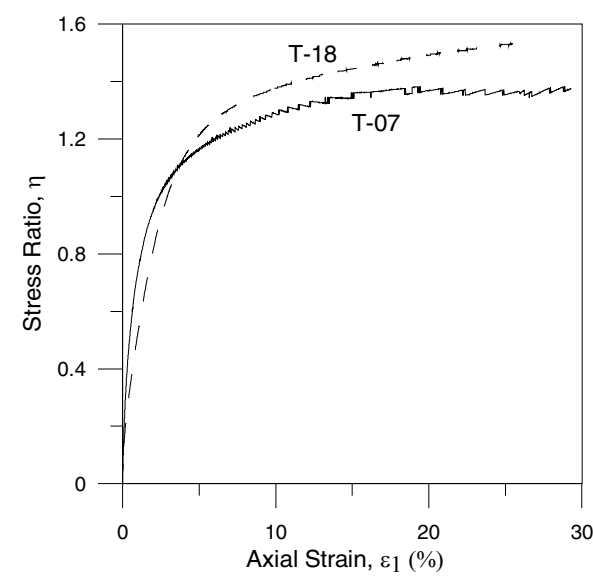

(d)

FIG. 2. Effect of host sand gradation on: (a) $q-p^{\prime}$ space, (b) $q$-axial strain, (c) pore water pressure generation $\left(\Delta \mathbf{u} / p^{\prime}{ }_{0}\right)$, (d) $\eta$-axial strain 
The ratio, $q_{\text {peak }} / q_{\mathrm{ss}}$, of WG-sand with fines varied from 1.10 for shearing from $p^{\prime}{ }_{0}$ of $850 \mathrm{kPa}$ to 1.80 for shearing from $p_{0}^{\prime}$ of $350 \mathrm{kPa}$. The ratio, $q_{\text {peak }} / q_{\mathrm{ss}}$ for Sydney sand with fines varied from 3.50 for shearing from $p_{0}^{\prime}$ of $850 \mathrm{kPa}$ to 11.50 for shearing from $350 \mathrm{kPa}$. So for both types of host sand (with very different $\mathrm{CU}$ ), liquefaction susceptibility decreased with $p^{\prime}{ }_{\mathrm{o}}$. However, Sydney sand with fines showed lower $q_{\mathrm{SS}}$ than WG-sand with fines irrespective of $p^{\prime}$. This finding is consistent with Vaid et al. (1991), liquefaction resistance increases with CU of host sand. The details experimental results are given in Table 2.

Figure 2(c) compares pore water pressure generation in a normalized form, $\Delta \mathrm{u} / p^{\prime}{ }_{\mathrm{o}}$, for T-18 (WG sand) and T-07 (Sydney sand). The pore water pressure generation of Sydney sand is much higher than that of WG-sand throughout undrained shearing. This is a main reason of the lower $q_{\text {SS }}$ of Sydney sand with fines. Figure 2(d) compares the mobilization of effective stress ratio with axial strain. Evidently the difference between T-18 (WG sand) and T-07 (Sydney sand) was small. Therefore, the influence has to be attributed to the gradation (not the inter-particle friction).

Table 2. Summary of tests used on the study

\begin{tabular}{|c|c|c|c|c|c|c|}
\hline $\begin{array}{c}\text { Test } \\
\text { Name }\end{array}$ & $\begin{array}{c}\text { Initial } \\
p_{0}^{\prime}(\mathbf{k P a})\end{array}$ & Sand & Fines & $\begin{array}{l}\text { Comp } \\
\text { arison }\end{array}$ & $\begin{array}{c}q_{\mathrm{SS}} \\
(\mathbf{k P a})\end{array}$ & $q_{\text {peak }} / q_{\mathrm{SS}}$ \\
\hline $\mathrm{T}-08$ & 350 & Sydney & M-Silt-II & \multirow{6}{*}{ 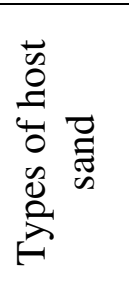 } & 9.10 & 11.50 \\
\hline $\mathrm{T}-05$ & 600 & Sydney & M-Silt-II & & 46.50 & 4.50 \\
\hline T-07 & 850 & Sydney & M-Silt-II & & 91.60 & 3.50 \\
\hline $\mathrm{T}-20$ & 350 & WG sand & M-Silt-II & & 78.10 & 1.80 \\
\hline $\mathrm{T}-19$ & 600 & WG sand & M-Silt-II & & 189.00 & 1.45 \\
\hline $\mathrm{T}-18$ & 850 & WG sand & M-Silt-II & & 486.00 & 1.10 \\
\hline NTC-01 & 600 & Sydney & No fines & \multirow{4}{*}{ 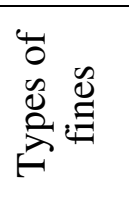 } & 278.10 & 1.40 \\
\hline NTC-08 & 600 & Sydney & S-Silt-I & & 153.80 & 2.67 \\
\hline NTC-11 & 600 & Sydney & S-Silt-II & & 139.60 & 2.56 \\
\hline $\mathrm{T}-05$ & 600 & Sydney & M-Silt-II & & 46.50 & 4.50 \\
\hline
\end{tabular}

\section{Effect of Fines Type}

The influence of fines type was investigated by testing Sydney sand mixed with different types of fines, viz, S-Silt-I, S-Silt-II and M-Silt-II. Fines content was fixed at $15 \%$. ICU test results are presented in Figs. 3(a-d) in the form of ESP, $q-\varepsilon_{1}$ curves, pore water pressure responses and $\eta-\varepsilon_{1}$ curve. Flow liquefaction was manifested in all three tests of sand-fines mix. However, the peak deviator strength and pre-peak ESP of sand with S-Silt-I and sand with S-Silt-II, and clean sand are similar, although the host sand only manifested limited flow. The peak strength of sand with M-Silt-II is considerably lower. The Steady State deviatoric strength, $q_{\mathrm{SS}}$, of these three sand-fines mix followed a similar trend. The deviatoric stress at steady state, $q_{\mathrm{SS}}$ for sand with SSilt-I fines is $153.80 \mathrm{kPa}$ which is slightly higher than that of sand with S-Silt-II at $139.60 \mathrm{kPa}$. However, the deviatoric stress at steady state, $q_{\mathrm{SS}}$ for sand with M-Silt-II is at a significantly lower value of $46.50 \mathrm{kPa}$. 
The only difference between S-Silt-I and S-Silt-II is that the latter was derived from the former by replacing $1 / 3$ of the synthetic silt with Kaolin, and thus introduced a small and controlled amount of plasticity to the fines. This only led to slight reduction in $q_{\text {peak }}$ and $q_{\text {ss. }}$. Therefore, the considerably inferior behaviour (lower $q_{\text {peak }}$ and lower $q_{\mathrm{ss}}$ ) for sand with M-Silt-II has to be attributed to factors other than plasticity for characterizing fines type.

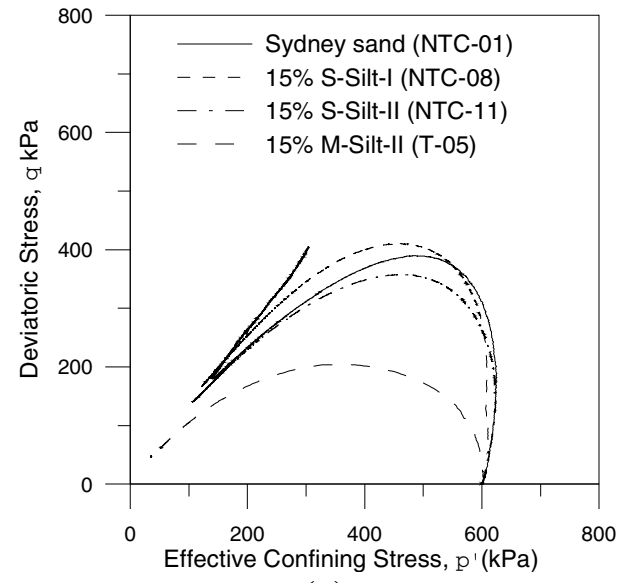

(a)

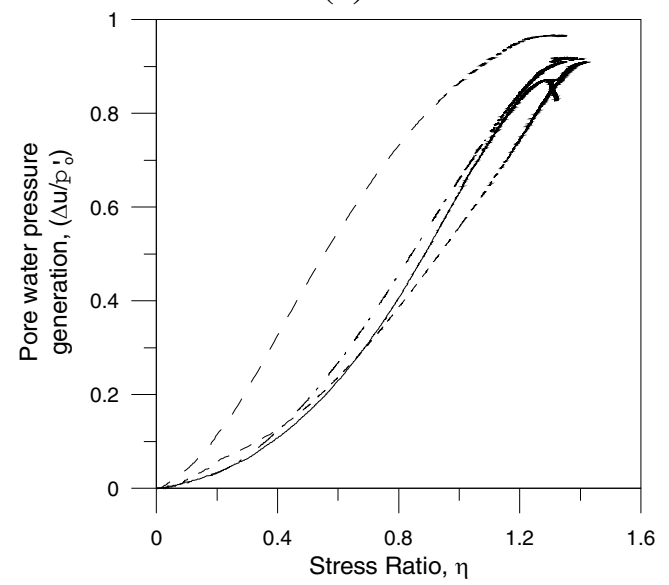

(c)

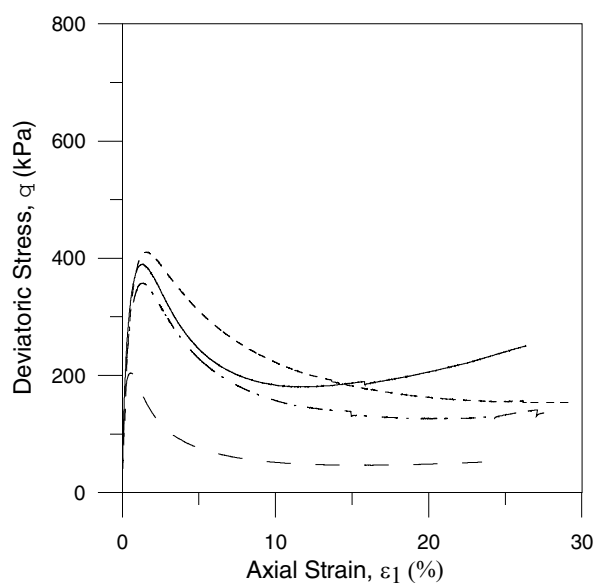

(b)

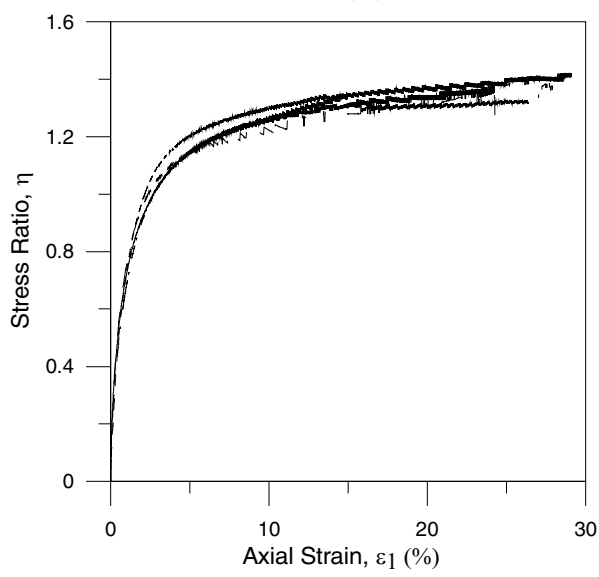

(d)

FIG. 3. Effect of fines type on Sydney sand: (a) $q$ - $p^{\prime}$ space, (b) $q$-axial strain, (c) pore water pressure generation $\left(\Delta \mathbf{u} / \boldsymbol{p}_{0}^{\prime}\right)$, (d) $\eta$-axial strain

\section{Scanning Electron Microscope (SEM) Photography}

To investigate the reason for the significant inferior behaviour (lower $q_{\text {peak }}$ and lower $q_{\mathrm{SS}}$ ) for sand with M-Silt-II, SEM photographs of S-Silt-I and M-Silt-II were taken. Two such photos were compared in Fig. 4. S-Silt-I consists of sharp, angular particle with a spiky surface; where as M-Silt-II is rounded and coated with "spongy" kaolin particles. It can be concluded from the photograph that angularity of fines plays an important role on the behaviour of a sand-fines mix. However, the adverse effect of SSilt-II on strength is not as much as M-Silt-II, though both of them contain one-third of kaolin. It indicates that angularity of fines may play higher contribution on sandfines mix strength than kaolin. 


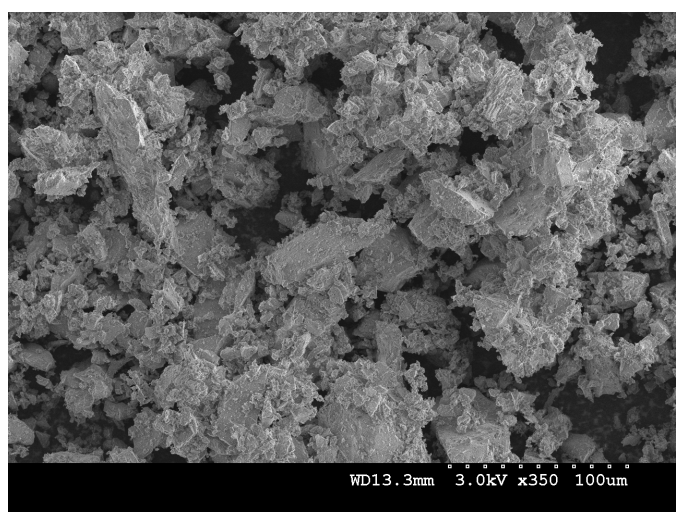

(a)

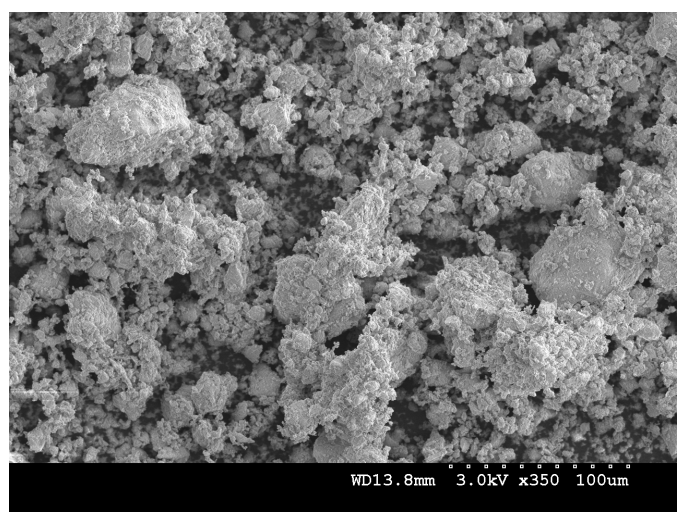

(b)

FIG. 4. SEM photograph of (a) S-Silt-I, (b) M-Silt-II

\section{Effect of Fines Type on Equivalent Granular Steady State Line}

The SSLs in $e-\log \left(p^{\prime}\right)$ space were plotted in Figure 5a, which showed that the addition of $15 \%$ fines, for all three fines type, the SSL shifted downward. This is consistent with previous studies. However the extent of downward shift depends on fines type. According to Rahman and Lo (2007b), the extent of shift depends on the particles diameter ratio, $r$. If this hypothesis can be extended to different fines type, a unique equivalent granular SSL line can be achieve irrespective of fines type, angularity and plasticity. Figure 4b showed that SS points of Sydney sand and Sydney sand with different types of fines. The data points all clustered around a narrow band and the concept of a unique equivalent granular SSL appears to be still applicable for capturing the effects of different type of fines. However, careful observation of the data points shows that some scatter from a unique relationship at low effective mean stress. It is considered that the angularity of fines may be the reason of the scatter and thus is another parameter for the determining of $e^{*}$.

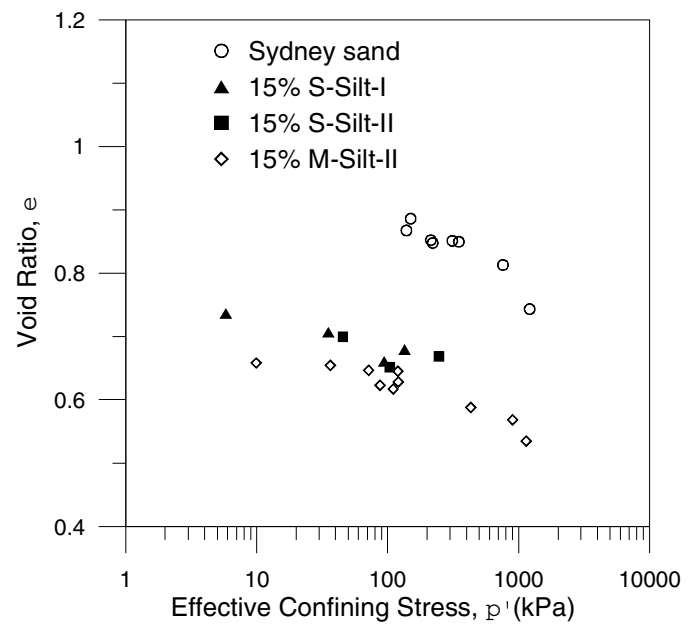

(a)

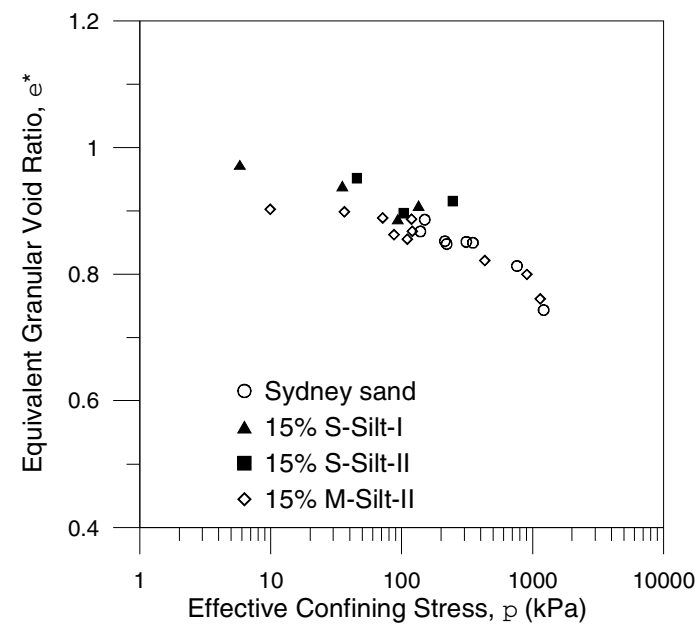

(b)

FIG. 5. (a) Effect of fines type on SSLs, (b) Unique equivalent granular SSL independent of fines type. 


\section{CONCLUSIONS}

The effect of sand gradation and fines type on liquefaction behaviour and their effect on equivalent granular void ratio formula were studied. The findings are as follows.

- The liquefaction behaviour of a sand fines mix, for a given fines type and content, depends on host sand gradation as represented by CU. It general, $q_{\mathrm{SS}}$ increases with CU.

- Angularity and plasticity of fines in a sand-fines mix play important role in liquefaction potential and SS strength. $q_{\mathrm{SS}}$ increases with angularity of fines and it can be attributed that angularity may have higher influence than plasticity on $q_{\mathrm{sS}}$. Again, liquefaction resistance decreases with increasing plasticity which is consistent with Sadek and Saleh (2007) but contradictory with Ghahremani et al. (2006) findings. Existence of threshold plasticity could be the reason of contradictory findings. Extensive investigation may need to draw a conclusion. However, liquefaction resistance of sand-fines mix always decreases with fines, no matter what is their type.

- The equation proposed by Rahman and Lo (2007b) for calculating " $b$ " and thus $e^{*}$, plus the conceptual framework of a unique equivalent granular SSL, can be used for sand with different types of fines. However, angularity of fines led to some scatter from a unique relationship in the $e^{*}-\log \left(p^{\prime}\right)$ space at low confining pressure. Thus, the equations used for determining $e^{*}$ may be further improved by considering angularity of fines.

\section{REFERENCES}

Bobei, D. C., and Lo, S. R. (2005). "Reverse behaviour and critical state of sand with small amount of fines." The Proceedings of the 16th International Conference on Soil Mechanics and Geotechnical Engineering (16ICSMGE), Japan, 475-478.

Chang, N. Y., Yey, S. T., and Kaufman, L. P. (1982). "Liquefaction potential of clean and silty sand." Proc. 3rd International Earthquake Microzonation Conference, 1018-1032.

Georgiannou, V. N., Burland, J. B., and Hight, D. W. (1990). "The undrained behaviour of clayey sands in triaxial compression and extension." Géotechnique, Vol. 40(3), 431-449.

Ghahremani, M., and Ghalandarzadeh, A. (2006). "Effect of plastic fines on cyclic resistance of sands." Soil and Rock Behavior and Modeling (GSP 150), Shanghai, China, 406-412.

Ghahremani, M., Ghalandarzadeh, A., and Moradi, M. (2006). "Effect of plastic fines on the undrained behavior of sands." Soil and Rock Behavior and Modeling (GSP 150), Shanghai, China, 48-54.

Kenney, T. C. (1977). "Residual strength of mineral mixture." Proc. 9th International Conference of Soil Mechanics and Foundation Engineering, 155-160.

Kuerbis, R., Negussey, D., and Vaid, Y. P. (1988). "Effect of gradation and fine content on the undrained response of sand." Hydraulic fill structure (GSP 21), ASCE, New York, 330-345.

Lo, S. R., Chu, J., and Lee, I. K. (1989). "A Technique for reducing membrane 
penetration and bedding errors." Geotechnical Testing Journal, Vol. 12(4), 311316.

Lo, S. R., Lade, P. V., and Wardani, S. P. R. (2003). "An experimental study of the mechanics of two weakly cemented soils." Geotechnical Testing Journal, Vol. 26(3), 328-341.

Lo, S. R., and Wardani, S. P. R. (2002). "Strength and dilatancy of a silt stabilized by cement and fly ash mixture." Canadian Geotechnical Journal, Vol. 39(1), 77.

Mitchell, J. K. (1976). Fundamental of soil behaviour, 1st edition, John Wiley \& Sons, Inc.

Perlea, V. G., Koester, J. P., and Prakasha, K. S. (1999). "How liquefiable are cohesive soils." Second International Conference on Earthquake Geotechnical Engineering and Soil Dynamics, Lisbon, Portugal, 611-618.

Rahman, M. M., and Lo, S. R. (2007a). "Equivalent granular void ratio and state parameters for loose clean sand with small amount of fines." 10Th Australia New Zealand Conference on Geomechanics, Brisbane, Australia, 674-679.

Rahman, M. M., and Lo, S. R. (2007b). "On intergranular void ratio of loose sand with small amount of fines." 16th South East Asian Geotechnical Conference, Kuala Lumpur, Malaysia, 255-260.

Rahman, M. M., Lo, S. R., and Gnanendran, C. T. (2007). "On equivalent granular void ratio and steady state behaviour of loose sand with fines." Canadian Geotechnical Journal, under second review.

Sadek, S., and Saleh, M. (2007). "The effect of carbonaceous fines on the cyclic resistance of poorly graded sands." Geotechnical and Geological Engineering, Vol. 25, 257-264.

Thevanayagam, S. (1998). "Effect of fines and confining stress on undrained shear strength of silty sands." Journal of Geotechnical and Geoenvironmental Engineering, Vol. 124(6), 479-491.

Thevanayagam, S. (1999). "Effect of fines and confining stress on the undrained shear strength of silty sands - Closure." Journal of Geotechnical and Geoenvironmental Engineering, Vol. 125(11), 1024-1027.

Thevanayagam, S., Fiorillo, M., and Laing, L. (2000). "Effect of non-plastic fines on undrained cyclic strength of silty sands." ASCE Geotechnical Special Publication, 99-91.

Thevanayagam, S., and Mohan, S. (2000). "Intergranular state variables and stressstrain behaviour of silty sands." Géotechnique, Vol. 50(1), 1-23.

Troncoso, J. H., and Verdugo, R. (1985). "Silt content and dynamic behaviour of tailing sands." Proc. 11th International Conference on Soil Mechanics and Foundation Engineering, 1311-1314.

Vaid, Y. P., Fisher, J. M., and Kuerbis, R. H. (1991). "Particle gradation and liquefaction." Journal of Geotechnical Engineering, Vol. 116(4), 698-703.

Yamamuro, J. A., and Lade, P. V. (1998). "Steady-State Concepts and Static Liquefaction of Silty Sands." Journal of Geotechnical and Geoenvironmental Engineering, Vol. 124(9), 868-877. 